\title{
Consequences of Postnatally Elevated Insulin-Like Growth Factor-II in Transgenic Mice: Endocrine Changes and Effects on Body and Organ Growth
}

\author{
ECKHARD WOLF*, RAINER KRAMER, WERNER F. RIJM, \\ JÜRGEN FÖLL, AND GOTTFRIED BREM* \\ Lehrstuhl für Molekulare Tierzucht, Ludwig-Maximilians-Universität (E.W., G.B.), D-80539 München; \\ Abteilung Neurochemie, Max-Planck-Institut für Psychiatrie (R.K.), D-82152 Martinsried; und Abteilung \\ Endokrinologie, Universitätskinderklinik (W.F.B., J.F.), D-72070 Tübingen, Germany
}

\begin{abstract}
Insulin-like growth factor-II (IGF-II) is an important regulator of embryonic growth and differentiation, but its function in postnatal life is unclear. To address this point, we generated transgenic mice harboring fusion genes in which a human IGF-II complementary DNA is placed under the transcriptional control of the rat phosphoenolpyruvate carboxykinase promoter. Transgene-specific messenger RNA was detected in liver, kidney, and several parts of the gut. Serum IGF-II levels in transgenic mice were 2-3 times higher than those in controls and increased after starvation. Circulating IGF-I correlated negatively and IGF-binding protein-2 (IGFBP-2) positively with IGF-II levels, suggesting that IGF-I is displaced from IGFBPs by IGF-II and that IGFII is a major regulator of IGFBP-2. Serum levels of IGFBP-3 and
\end{abstract}

IGFBP-4 tended to be higher in phosphoenolpyruvate carboxykinaseIGF-II transgenic mice than in controls, as evaluated by ligand blot analysis. Starvation reduced serum IGF-I, but increased IGFBP-2 in transgenic mice more markedly than in controls. Fasting insulin levels were significantly reduced in transgenic mice, whereas glucose levels were not influenced by elevated IGF-II. The body growth of 4- and 12week-old mice was not significantly influenced by elevated IGF-II, but transgenic mice displayed increased kidney and testis weight at the age of 4 weeks, and increased adrenal weight at the age of 12 weeks. Our results demonstrate that elevated IGF-II in postnatal life has multiple endocrine consequences and subtle time-specific effects on organ growth. (Endocrinology 135: 1877-1886, 1994)
A LTHOUGH the biological roles of insulin-like growth factor-I (IGF-I) as both a hormone and a paracrine growth factor are becoming increasingly clearer (for review, see Refs. 1 and 2), no overall concept has emerged of the physiological function of IGF-II in growth and metabolism.

The role of IGF-II has widely been postulated to be a fetal growth-promoting hormone. The most direct evidence for this was provided by DeChiara et al. (3), who inactivated the IGF-II gene in mice by gene targeting. The growth of fetuses lacking functional IGF-II expression was impaired, but postnatal growth paralleled that of control littermates, suggesting that IGF-II does not play a major role in postnatal growth. These studies also demonstrated that the mouse IGF-II gene is subject to genomic imprinting and that only the paternal allele is active (4). Furthermore, IGF-II is known to stimulate the growth and metabolism of preimplantation mouse embryos in vitro (5).

IGF-II messenger RNA (mRNA) expression is high in most fetal tissues and declines after birth, except in neural tissue (6-8). Postnatal plasma levels of IGF-II are essentially low in rats and mice, but in other species, such as sheep and guinea pig, serum IGF-II levels decline somewhat after birth, but stay relatively high (2). In man, postnatal levels are even

Received April 15, 1994

Address requests for reprints to: Dr. Eckhard Wolf, Lehrstuhl für Molekulare Tierzucht, Ludwig-Maximilians-Universität, Veterinärstrasse 13, D-80539 München, Germany.

* Present address: Institut für Tierzucht und Genetik, Veterinärmedizinische Universität, Linke Bahngasse 11, A-1030 Wien, Austria higher than prenatal levels; they increase with gestational age and rise during the first weeks of life, with no pubertal increase $(9,10)$. Postnatal IGF-II expression in man is driven by an alternative promoter, which starts after birth and confers IGF-II gene expression mainly in the liver $(11,12)$.

Elevated IGF-II expression is found in a variety of malignancies in humans (for review, see Ref. 13), in liver tumors of transgenic mice harboring the early region of simian virus40 under the control of either human antithrombin-III regulatory sequences $(14,15)$ or the major urinary protein (MUP) promoter (15), and in hepatic neoplasms in transgenic mice containing the pre- $S / S$ region of hepatitis-B virus controlled by the mouse albumin promoter and enhancer (15).

The failure to demonstrate clear roles for IGF-II in postnatal growth physiology and pathology invited the generation of an animal model with postnatally elevated IGF-II mRNA and protein. We, therefore, produced transgenic mice carrying fusion genes in which a human IGF-II complementary DNA (cDNA) is placed under the transcriptional control of the rat phosphoenolpyruvate carboxykinase (PEPCK) promoter. In this first study, we investigated the dietary regulation of PEPCK-IGF-II transgene expression and effects on IGF-I, IGF-binding proteins (IGFBPs), insulin, and glucose levels. Furthermore, we characterized the effects of elevated IGF-II on body and organ growth at 4 and 12 weeks of age.

\section{Materials and Methods}

\section{Construction of the PEPCK-IGF-II gene construct}

A 550-basepair (bp) fragment of the PEPCK promoter was amplified from the plasmid pTZ18R-PEPCK- $\beta$-globin (a gift from Dr. St. Rose- 
John, Institut für Biochemie, RTWH Aachen, Germany) by polymerase chain reaction. PEPCK promoter-specific sense and antisense oligonucleotides 5'-CGTACGACTAGTGAATTCCCTTCTCATGACCTTT-3' and 5'-CTTTAGGCCGCTCTGCGAGACTCGAGCGCTAG-3' were designed according to the available DNA sequence in the GENBANK database (accession no. $\mathrm{KO}_{2} 299$ ), including a flanking SpeI site (italicized) in the sense oligo and a SacI site (italicized) in the antisense oligo. The polymerase chain reaction product was blunted by T4 DNA polymerase and inserted into the Smal site of pBluescript II KS (Stratagene, La Jolla, CA). The DNA sequence was verified by automatic sequencing with the Bio-Rad sequencing system (Richmond, CA). The PEPCK promoter was inserted up-stream of the rat insulin-II intron A as a SpeISacl fragment in a mammalian expression vector based on pCMV5, resulting in pPEPCK-int. Finally, a 768-bp BamHI-PstI fragment spanning the coding region of the human IGF-II gene (16) and $80 \mathrm{bp}$ of the $5^{\prime}$-untranslated region (17) was isolated from vector pUC12-IGF-II (obtained from Dr. R. Koshy, Department of Virology, Royal Postgraduate Medical School, London, United Kingdom) and cloned into pPEPCK-int down-stream of the rat insulin II intron. From the resulting plasmid PEPCK-int-IGF-II, a 2-kilobase (kb) SpeI-BstXI fragment was excised, gel purified, and used for microinjection. The fragment includes $550 \mathrm{bp}$ of the PEPCK promoter, $120 \mathrm{bp}$ of rat insulin II intron A sequences, the IGF-II-coding region, and $420 \mathrm{bp}$ of the terminating sequences of the human GH gene (Fig. 1).

\section{Production of transgenic mice and animal husbandry}

A solution containing $2 \mu \mathrm{g} / \mathrm{ml}$ of the DNA fragment described above in $10 \mathrm{mmol} / \mathrm{liter}$ Tris- $\mathrm{HCl}(\mathrm{pH} 7.4)$ and $0.25 \mathrm{mmol} /$ liter EDTA buffer was used for microinjection into pronuclei of zygotes from superovulated B6D2F1 mice. Injected zygotes were transferred to synchronized recipients (NMRI). Mice were purchased from Charles River-WIGA (Sulzfeld, Germany).

The presence of the PEPCK-IGF-II gene construct in 3-week-old animals was shown by Southern blot analysis. DNA was extracted from tail tips according to previously described methods (18). Aliquots $(10 \mu \mathrm{g})$ were digested with PstI, fractionated on $1 \%$ agarose gels in $1 \times$ TBE ( 89 $\mathrm{mmol} /$ liter Tris-borate and $1 \mathrm{mmol} / \mathrm{liter}$ EDTA), and blotted under alkali conditions to Hybond $\mathrm{N}+$ membranes (Amersham, Arlington Heights, IL). Filters were prehybridized for $3 \mathrm{~h}$ at $65 \mathrm{C}$ in $1 \mathrm{~mol} /$ liter $\mathrm{NaCl}, 1 \%$ sodium dodecyl sulfate (SDS), $1 \mathrm{mmol} / \mathrm{liter}$ EDTA, and 10 $\mathrm{mmol} /$ liter Tris- $\mathrm{HCl}$ containing $10 \%$ dextran sulfate. Hybridization was performed overnight in the same buffer containing a ${ }^{32} \mathrm{P}$-labeled $\left(10^{7}\right.$ $\mathrm{cpm} / \mathrm{ml}$ ) 782-bp IGF-II cDNA probe excised from PUC12-IGF-II with PstI. The membranes were washed for $10 \mathrm{~min}$ at room temperature in 2 $\times$ SSC $\left(0.3 \mathrm{~mol} /\right.$ liter $\mathrm{NaCl}, 0.03 \mathrm{~mol} /$ liter $\mathrm{Na}_{3}$ citrate $\left.\cdot 2 \mathrm{H}_{2} \mathrm{O}\right)$ and twice for $30 \mathrm{~min}$ at $65 \mathrm{C}$ in $0.1 \times \mathrm{SSC}$ containing $1 \%$ SDS and then exposed to $x$-ray film (X-Omat, Eastman Kodak, Rochester, NY).

Transgenic founder animals were mated to nontransgenic mice to set up transgenic lines. All animals were kept under conventional (nonbarrier) conditions and had free access to pelleted diet (Altromin 1324; Altromin, Lage, Germany) and tap water. A detailed description of housing conditions, including the pathogens present in the colony, was provided previously (19).

\section{RNA analysis}

Tissue samples $(\sim 100 \mathrm{mg})$ were obtained from PEPCK-IGF-II transgenic mice and nontransgenic littermates and immediately frozen in

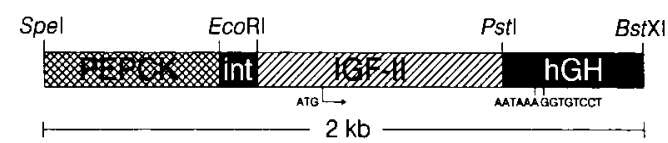

FIG. 1. Schematic representation of PEPCK-IGF-II. The construct was cloned as described in Materials and Methods and includes the 550-bp PEPCK promoter, 120-bp rat insulin II intron A sequences, the 768-bp human IGF-II cDNA, and 420 bp of the terminating sequences of the human $\mathrm{GH}$ gene. Restriction sites as well as translation initiation (ATG) and transcription termination (AATAAA and GGTGTCCT) are indicated. liquid nitrogen. For analysis, the tissues were homogenized in $2 \mathrm{ml} 4$ mol/liter guanidine thiocyanate using an Ultra-Turrax System T25 Janke \& Kunkel, Staufen, Germany). RNA was further purified by isopycnic gradient centrifugation in cesium trifluoroacetate (20), quantified by UV spectrometry, glyoxylated, and fractionated on a $1.1 \%$ agarose gel. Electrophoresed RNA was transferred to Hybond N filters (Amersham), which were hybridized with an IGF-II-specific ${ }^{32} \mathrm{P}$-labeled complementary RNA probe produced by Amersham multiprime labeling system. The complementary RNA probe was obtained by in vitro transcription of the PstI IGF-II fragment from pUC12-IGF-II, which had been cloned into $\mathrm{pBluescript} \mathrm{II} \mathrm{KS} \mathrm{(Stratagene).} \mathrm{Hybridization} \mathrm{was} \mathrm{carried} \mathrm{out} \mathrm{under}$ stringent conditions in $50 \mathrm{mmol} /$ liter sodium phosphate buffer containing $50 \%$ formamide, $6 \times$ SSC, $10 \mathrm{mmol} /$ liter EDTA, $2 \times$ Denhardt's solution $(0.4 \mathrm{~g} /$ liter Ficoll $400,0.4 \mathrm{~g} /$ liter polyvinylpyrrolidone, and 0.4 $\mathrm{g} /$ liter BSA), $1 \%$ SDS, and $250 \mu \mathrm{g} / \mathrm{ml}$ denaturated salmon sperm DNA at $50 \mathrm{C}$ for $12 \mathrm{~h}$. Filters were washed in $0.2 \times$ SSC- $0.5 \%$ SDS at $65 \mathrm{C}$ for $30 \mathrm{~min}$ before autoradiography. The size of the mRNA transcripts was determined by comparison of relative mobilities with a RNA size standard (Gibco-BRL, Gaithersburg, MD). As a loading control and to check the integrity of the RNA samples, filters were stained by methylene blue (21) after autoradiography.

\section{Serum sampling, hormone and IGFBP assays, and glucose determination}

Blood samples were taken by orbital puncture from mice under ether anesthesia; these were stored at $4 \mathrm{C}$ for $30 \mathrm{~min}$ and centrifuged twice for $10 \mathrm{~min}$ each time at $15,000 \times g$ to obtain serum. Fasting serum samples were taken after a $14-\mathrm{h}$ food deprivation period. Serum samples were stored in $100-\mu$ laliquots at $-20 \mathrm{C}$ until further analysis.

Serum concentrations of IGF-II, IGF-I, and IGFBP- 2 were determined by RIA, as described previously $(10,22,23)$. For IGF-II measurements, serum samples were extracted by acid-ethanol. Residual BPs in the extract were blocked with an excess of recombinant human IGF-I (25 $\mathrm{ng} /$ tube). For IGF-I determination, acid-ethanol extraction was not necessary due to the high affinity of the first antibody. Serum samples were diluted 1:150 with a $10 \mathrm{~mm}$ phosphate buffer ( $\mathrm{pH} \mathrm{2.8)}$ to dissociate IGFs from IGFBPs. Upon reneutralization with assay buffer, an excess of recombinant human IGF-II (Mediagnost, Tübingen, Germany) was added simultaneously to block IGFBP-binding sites. For IGFBP-2 measurements, serum samples were diluted 1:30 in assay buffer.

Ligand blot analysis of serum IGFBPs was performed according to the method of Hossenlopp et al. (24), using [225I]IGF-II as tracer. Serum samples were diluted 1:3 with PBS before analysis. Quantitative evaluation of ligand blots was carried out according to the method of Zapf $e t$ al. (25) by cutting out marked bands from the nitrocellulose membrane and counting them in a $\gamma$-counter.

Serum insulin concentrations were measured using a commercially available RIA kit (INSULIN-CT, CIS Bio International, Gif-sur-Yvette, France) for human insulin with $89.5 \%$ cross-reactivity for rat insulin. Intraassay coefficients of variation were $9.3 \%$ and $2.2 \%$ (five replicates) for mouse serum samples containing 17.2 and $50.4 \mu \mathrm{IU}$ insulin $/ \mathrm{ml}$, respectively. The interassay coefficient of variation was $9.7 \%$ (three replicates) for the sample containing $17.2 \mu \mathrm{IU}$ insulin $/ \mathrm{ml}$.

Fasting serum glucose levels were determined using the GlucoquantHexokinase method on a Reflotron analyzer (Boehringer Mannheim, Germany).

\section{Analysis of body and organ growth}

Body weight and body dimensions as well as organ weights of PEPCK-IGF-II transgenic mice and littermate controls were determined at 4 and 12 weeks of age. After taking the body weight, animals were killed by an overdose of ketamine and xylazine. External body dimensions (crown-rump length, nose-rump length, and total body length) were determined as described previously (26). Heart, lung, spleen, pancreas, kidneys, adrenal glands, liver, gastroenteric tract, thymus, salivary glands, brain, and testes were dissected, blotted dry on tissue paper, and weighed to the nearest milligram. Furthermore, the weight of mesentery and fat tissue surrounding the genital organs and kidneys was determined, as the amount of intraabdominal fat tissue is correlated 
with the total body fat content (27). Finally, the weights of skin and empty carcass were determined to the nearest gram.

\section{Statistical analysis}

Analysis of variance was performed on data obtained from PEPCKIGF-II transgenic mice and controls for hormone and glucose levels as well as body measurements and organ weights. A statistical model was designed to estimate the effects of group (transgenic or control), sex, age, and the interaction between group and sex. The general linear models procedure (28) was used to calculate least squares means (LSMs) and SES of LSMs. Statistically significant differences between LSMs were verified using Student's $t$ tests. The effects of fasting on IGF-II, IGF-I, IGFBP-2 and insulin levels within each group were statistically evaluated using the Wilcoxon matched pairs signed rank test. The Wilcoxon rank sum test was used to compare IGFBP levels detected in serum from transgenic mice and controls by ligand blot analysis.

\section{Results}

\section{Construction of PEPCK-IGF-II and generation of transgenic} mice

As outlined in Fig. 1, a human IGF-II cDNA was placed under the transcriptional control of $550 \mathrm{bp}$ of the PEPCK promoter. According to the findings of Palmiter et al. (29), we introduced a heterologous intron [intron $\mathrm{A}$ of the rat insulin II (ins-2) gene] up-stream of the IGF-II cDNA to facilitate expression in transgenic mice.

Two transgenic founder mice (525-41 and 526-51) were produced by pronuclear microinjection, which transmitted the PEPCK-IGF-II transgenes to their offspring. Southern blot analyses of DNA samples from F1 offspring are shown in Fig. 2. The percentage of transgenic offspring indicated that both founder mice were mosaics. In subsequent gener-

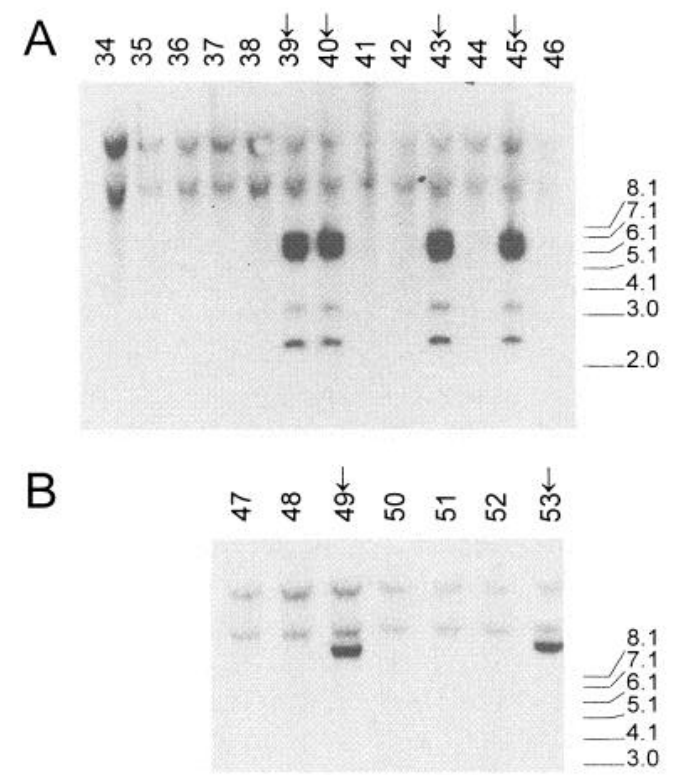

FIG. 2. Southern blot analysis of F1 offspring from founder animals 525-41 (A) and 526-51 (B). Tail DNA (10 $\mu \mathrm{g})$ was digested with PstI, electrophoresed, and blotted, as described in Materials and Methods. The blots were hybridized with a ${ }^{32} \mathrm{P}$-labeled 782-bp IGF-II cDNA probe, washed, and exposed to x-ray film $(36 \mathrm{~h})$. Transgenic animals are marked by arrows; mol wt markers are shown at the right of the blots. ations, matings of hemizygous transgenic mice with controls produced about $50 \%$ transgenic offspring. All transgenic mice investigated in this study were hemizygotes, and all controls were their nontransgenic littermates.

\section{Expression of PEPCK-IGF-II gene constructs}

Steady state levels of PEPCK-IGF-II mRNA expression were studied by Northern blot analysis of total RNA from a variety of organs. RNA from liver, kidney, and intestine, major sites of endogenous PEPCK expression $(30,31)$, were used to compare transgenic animals from both lines with controls. A transgene-specific RNA of about $1 \mathrm{~kb}$ was detected in organ samples from line 525-41 (Fig. 3A). We, therefore, concentrated our further studies on this line and tested a wide spectrum of organs for PEPCK-IGF-II-specific
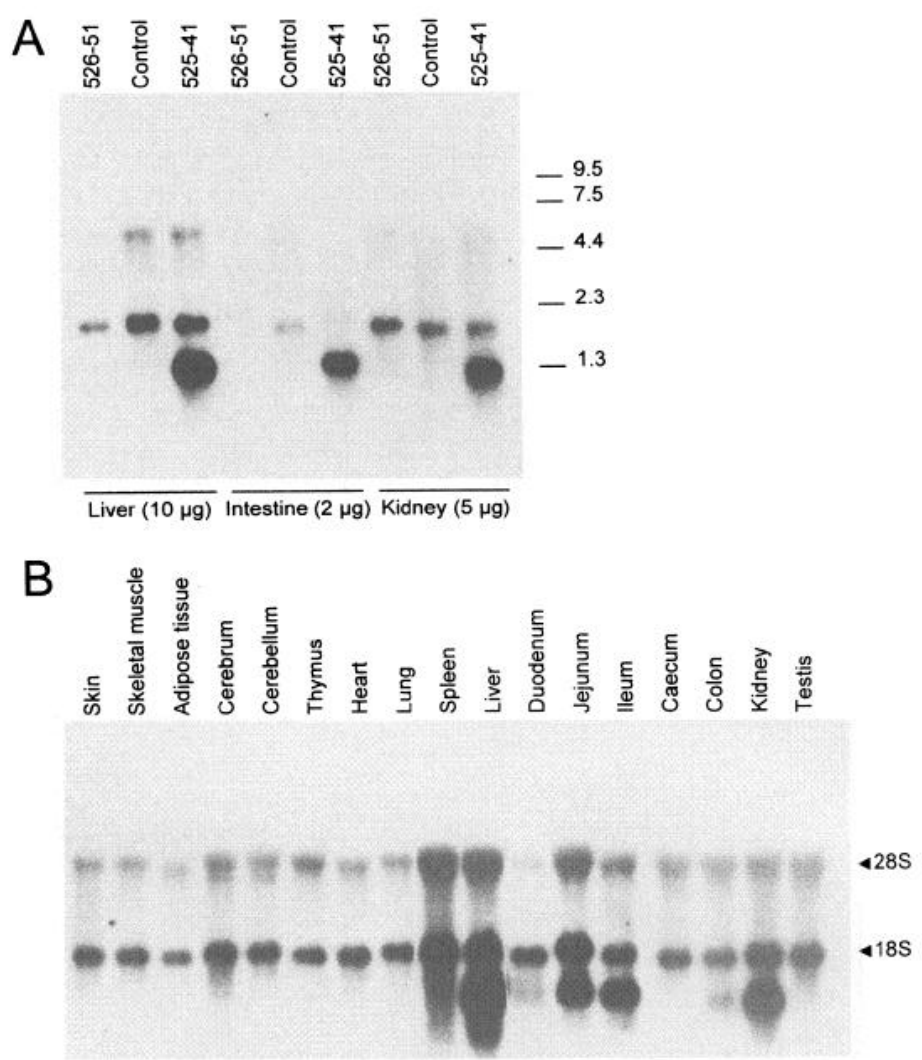

FIG. 3. Northern blot analysis of steady state levels of PEPCK-IGFII-specific mRNA. A, Comparison of the two transgenic lines with controls. Total RNA was purified from liver, intestine, and kidney of 9-week-old transgenic mice and a control after a 14-h fasting period, as described in Materials and Methods, glyoxylated, electrophoresed on $1.1 \%$ agarose gels, transferred to Hybond $\mathrm{N}$ filters (Amersham), and hybridized with a ${ }^{32} \mathrm{P}$-labeled IGF-II riboprobe. After washing under stringent conditions, the filter was exposed to $\mathrm{x}$-ray film $(8 \mathrm{~h})$. The amount of RNA loaded per slot is indicated as well as the relative mobility of mol wt markers (right side). A transgene-specific transcript of about $1 \mathrm{~kb}$ was detected in line 525-41. B, Expression pattern of line 525-41. Total RNAs from 17 different tissues of an ad libitum-fed 12 -week-old male transgenic mouse were subjected to Northern blot analysis, as described above. From the organs investigated, transgenespecific transcripts were present in liver, duodenum, jejunum, ileum, colon, and kidney. The relative mobilities of $18 \mathrm{~S}$ and $28 \mathrm{~S}$ ribosomal RNAs are indicated at the right side. 
mRNA expression. In addition to liver and kidney, we detected a transgene-specific transcript in several parts of the gut (duodenum, jejunum, ileum, and colon, but not caecum). No PEPCK-IGF-II expression was found in adipose tissue (Fig. 3B).

Serum IGF-II concentrations in transgenic mice belonging to line 525-41 were 2- to 3-fold higher than those in controls, with significantly greater IGF-II levels in male than in female mice (Fig. 4A). Circulating IGF-II levels were not different between transgenic animals younger or older than 12 weeks (Fig. 4B). After a 14-h fasting period, circulating IGF-II levels increased in transgenic mice $(P<0.05)$, but decreased in controls $(P<0.01)$, suggesting correct nutritional control of the PEPCK promoter-driven transgene (Fig. 5).

Effects of elevated IGF-II on IGF-I, IGFBP, insulin, and glucose levels

Overall, serum IGF-I concentrations were lower in IGF-II transgenic mice than in controls. LSMs and SEs (in parentheses) of LSMs calculated for transgenic and control mice using the statistical model outlined in Materials and Methods were
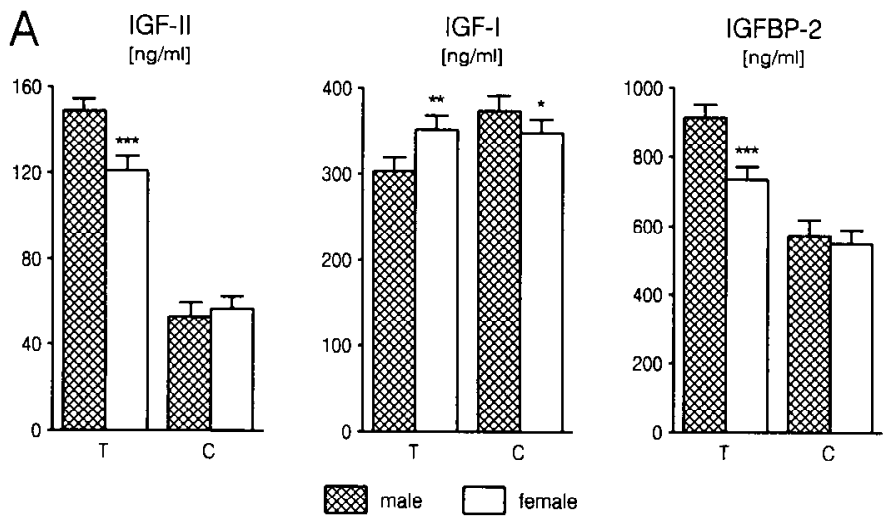
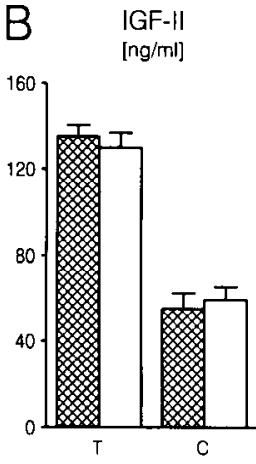

IGF-I

$[\mathrm{ng} / \mathrm{ml}]$

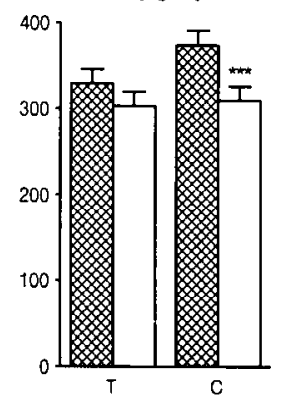

IGFBP-2

[ng/ml]

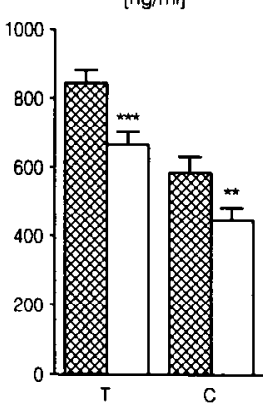

$\leq 12$ weeks $\square>12$ weeks

Fig. 4. Effects of sex (A) and age (B) on concentrations of IGF-II, IGF-I, and IGFBP-2 in serum samples from PEPCK-IGF-II transgenic mice and controls. Measurements were performed as described in Materials and Methods in 99 serum samples from transgenic mice (425 weeks old) and in 132 serum samples from controls (4-20 weeks old). Analysis of variance was used to calculate LSMs (columns) and SE (error bars) for male and female mice (A) or mice belonging to different age classes (B). Significant differences are marked by asterisks: ${ }^{*}, P<0.05{ }^{* *}, P<0.01{ }^{* * *}, P<0.001$.
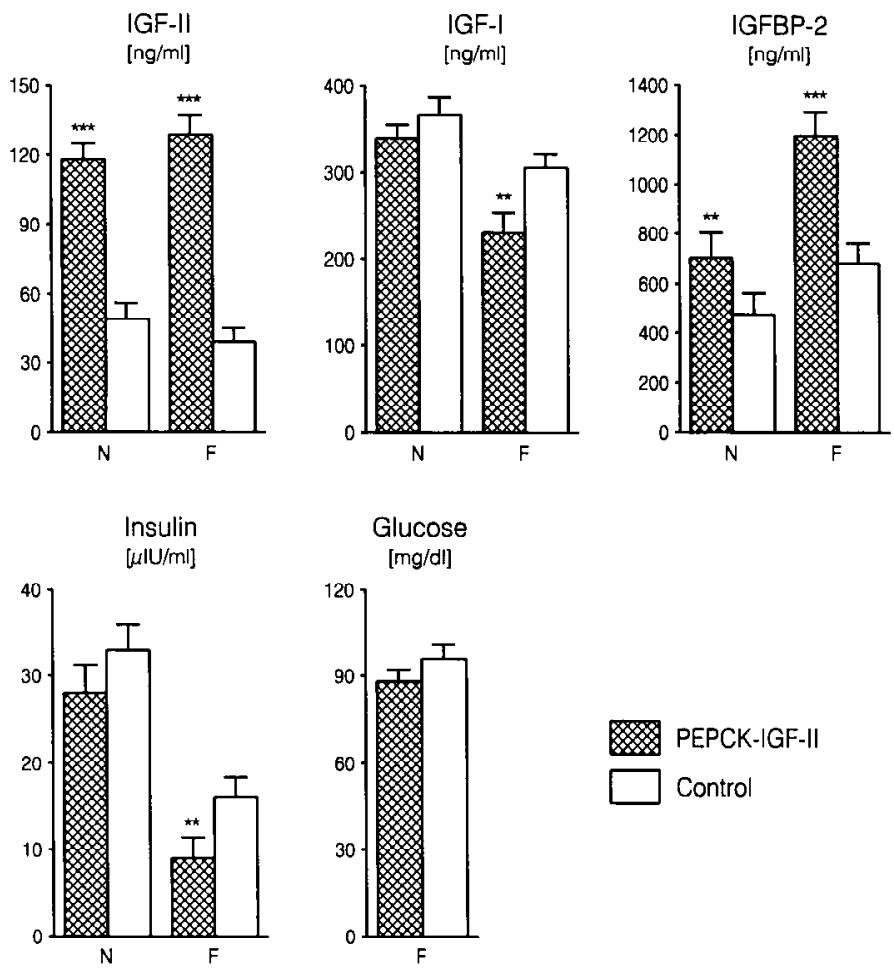

PEPCK-IGF-II Control

FiG. 5. Effects of fasting on concentrations of IGF-II, IGF-I, IGFBP2 , insulin, and glucose in serum samples from PEPCK-IGF-II transgenic mice and littermate controls. Serum samples were obtained from 10 - to 20-week-old transgenic mice $(n=11)$ and controls $(n=12)$ before $(\mathrm{N})$ and after $(\mathrm{F})$ a 14 -h food deprivation period. Measurements were carried out, and data were subjected to analysis of variance as described in Materials and Methods. Columns represent LSMs estimated for transgenic mice and controls. SEs of LSM are shown as error bars. Significant differences between LSMs from both groups are marked by asterisks: ${ }^{* *}, P<0.01$; ${ }^{* *}, P<0.001$.

$327.9(7.4)$ and $362.0(6.5)$, respectively $(P<0.001)$. Sexrelated differences in IGF-I levels were seen in both groups of mice. Transgenic males displayed significantly lower IGFI levels than transgenic females, suggesting a negative relationship between IGF-I and IGF-II levels (Fig. 4A). A negative correlation between IGF-II and IGF-I levels in PEPCK-IGFII transgenic mice was also shown by linear regression analysis (Fig. 6A). Serum IGF-I levels in male controls were significantly higher than those in control females (Fig. 4A). An effect of age on serum IGF-I concentrations was seen in the control group in which animals younger than 12 weeks had significantly higher levels than older mice.

Serum IGFBP-2 was significantly elevated in PEPCK-IGFII transgenic mice, with a sex-related difference mirroring that observed with IGF-II (Fig. 4A). In contruls, IGFBP-2 levels in male and female mice were not significantly different. An effect of age was seen in both groups of mice investigated (Fig. 4B): animals younger than 12 weeks had significantly higher IGFBP-2 values than older animals.

Linear regression analysis revealed a significant positive correlation between serum IGF-II and IGFBP-2 levels as well as a significant negative correlation between serum IGF-I and IGFBP-2 in PEPCK-IGF-II transgenic mice (Fig. 6, B and C). 

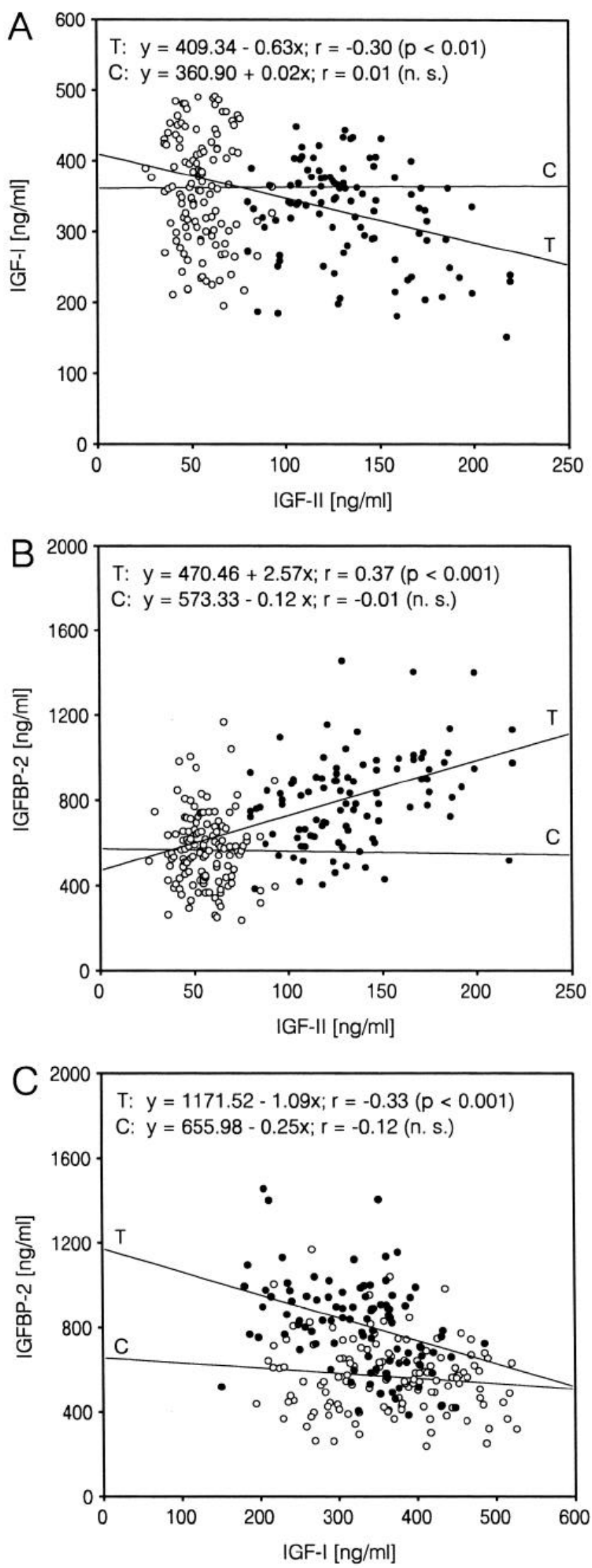

A

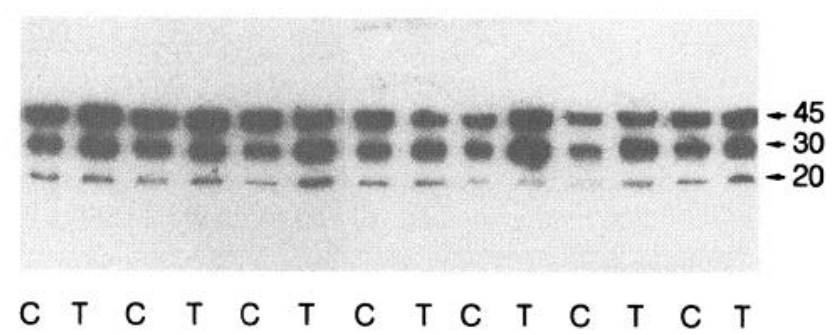

B

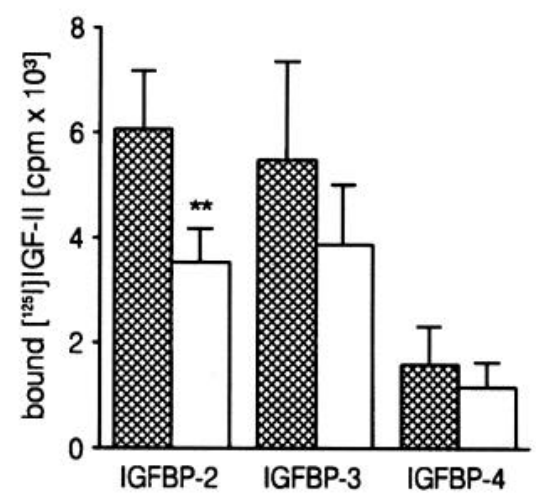

PEPCK-IGF-II

Control

FIG. 7. Ligand blot analysis of IGFBPs in serum from 12-week-old PEPCK-IGF-II transgenic mice (T) and controls (C). A, Ligand blot analysis was carried out as described in Materials and Methods, using $\left[{ }^{125} \mathrm{I}\right]$ IGF-II as tracer. The relative mol wt of IGFBP-3 $(45 \mathrm{kDa})$, IGFBP-2 $(30 \mathrm{kDa})$, and IGFBP-4 $(20 \mathrm{kDa})$ is indicated at the right side. B, IGFBPs were quantified as described in Materials and Methods. The graph shows the means and SDs. Serum IGFBP-2 in transgenic mice was significantly higher than that in controls $(P<0.01)$. Furthermore, transgenic mice tended to have elevated serum concentrations of IGFBP-3 $(P=0.0736)$ and IGFBP-4 $(P=0.0967)$.

Ligand blot analysis of serum from 12-week-old animals confirmed the difference in IGFBP-2 levels between transgenic mice and controls. Similarly, serum concentrations of IGFBP-3 and IGFBP-4 tended to be higher in transgenic mice than in controls (Fig. 7).

\section{Effects of fasting on IGF-I, IGFBP-2, insulin, and glucose levels}

These effects are summarized in Fig. 5. After a 14-h fasting period, serum IGF-I levels were reduced in both groups of mice $(P<0.01)$, but more markedly in transgenic mice than in controls, reflecting again the negative relationship between IGF-II and IGF-I.

IGFBP- 2 was up-regulated by fasting in both groups of mice investigated, again more markedly in transgenic mice $(70 \% ; P<0.001)$ than in controls $(40 \% ; P<0.01)$.

Under ad libitum feeding, serum insulin concentrations were slightly, but not significantly, lower in transgenic mice than in controls, whereas $14-\mathrm{h}$ food deprivation resulted in significantly reduced insulin levels in transgenic mice com-

FIG. 6. Linear regressions and correlations between IGF-II and IGF-I (A) as well as IGF-II and IGFBP-2 (B) and IGF-I and IGFBP-2 (C) in serum samples from PEPCK-IGF-II transgenic mice $(\mathrm{T} ; \bullet)$ and controls $(\mathrm{C} ; \mathrm{O})$. 
pared to controls. In contrast, fasting glucose levels were not significantly different between the two groups of mice.

\section{Effects of elevated IGF-II on body and organ growth}

Data obtained from 4- and 12-week-old PEPCK-IGF-II transgenic mice and controls are presented in Tables 1 and 2. Although there were no significant differences between the groups, transgenic mice displayed slightly higher values for body weight, body dimensions, carcass weight, and abdominal fat at 4 weeks of age. In 12-week-old animals, all of these differences were absent (Table 1).

Determination of organ weights (Table 2) revealed significantly greater kidney and testis weights for 4-week-old transgenic mice than for age-matched controls. The mean kidney weight of transgenic mice was also increased when related to body weight $\left(6.5 \times 10^{-3}\right.$ vs. $\left.6.1 \times 10^{-3} ; P<0.05\right)$. At 12 weeks of age, there were no significant differences in kidney or testis weight, but transgenic mice displayed significantly higher weights of the adrenal glands than controls ( $P$ $<0.05)$. The difference in mean relative adrenal weight $(1.8$ $\times 10^{-4}$ vs. $\left.1.5 \times 10^{-4}\right)$ reached the borderline of statistical significance $(P=0.0551)$.

\section{Discussion}

The biological activities of IGFs in vivo have been subject to extensive research. A number of studies $(3,4,32-34)$ used the gene targeting approach to generate mice deficient for IGF-II, IGF-I, IGF type 1 receptor, or combinations of these. Analysis of phenotypes resulting from the lack of IGFs and/ or their receptors provided a plethora of new aspects concerning their roles in prenatal and postnatal development. However, the evidence given is indirect, because conclusions are drawn from null mutants. Therefore, many studies on the biological function of IGF-II involved experimental designs with artificially increased local or circulating levels of IGF-II.

Exogenous application of IGFs allows only short studies and may cause immunological problems if heterologous proteins are used. Transplantation of IGF-II-secreting tumors into nude mice or rats $(35,36)$ provides a model for prolonged studies. However, standardization of these experiments is difficult because tumor growth may be variable and can compromise the animals.

To overcome these problems, we generated transgenic mice expressing human IGF-II under the control of the PEPCK promoter. The gene coding for PEPCK (GTP; EC 4.1.1.32), a pace-setting enzyme in gluconeogenesis, is expressed in multiple tissues and regulated in a complex tissuespecific manner $(37,38)$. In the liver, cAMP, glucocorticoids, thyroid hormone, PRL, and retinoic acid are inducers, and insulin and diacylglycerol are inhibitors of expression (38). A bovine $\mathrm{GH}$ gene controlled by 460 bp of the rat PEPCK promoter was shown to follow the expression of the endogenous PEPCK gene with respect to both developmental pattern and tissue specificity. Expression started on day 19 of fetal development and increased about 200-fold after birth (39). Expression was detected in liver, kidney, intestine, adipose tissue, and mammary gland $(30,31)$. Starvation stimulated expression of the PEPCK promoter-regulated

TABLE 1. Serum IGF-II, body weight, external body dimensions, skin weight, carcass weight, and abdominal fat of PEPCK-IGF-2 transgenic mice $(\mathrm{T})$ and nontransgenic littermates $(\mathrm{C})$

\begin{tabular}{|c|c|c|c|c|c|c|c|}
\hline \multirow{2}{*}{ Parameter } & \multirow{2}{*}{ Group } & \multicolumn{3}{|c|}{ Age 4 weeks } & \multicolumn{3}{|c|}{ Age 12 weeks } \\
\hline & & LSM & SE & $P$ & LSM & SE & $P$ \\
\hline Serum IGF-II (ng/ml) & $\begin{array}{l}\mathrm{T} \\
\mathrm{C}\end{array}$ & $\begin{array}{r}135.23 \\
60.17\end{array}$ & $\begin{array}{l}5.35 \\
4.46\end{array}$ & $\begin{array}{l}0.0001 \\
a\end{array}$ & $\begin{array}{r}137.18 \\
52.61\end{array}$ & $\begin{array}{l}4.38 \\
4.38\end{array}$ & $\underset{a}{0.0001}$ \\
\hline BW (g) & $\begin{array}{l}\mathrm{T} \\
\mathrm{C}\end{array}$ & $\begin{array}{l}16.87 \\
15.49\end{array}$ & $\begin{array}{l}0.66 \\
0.55\end{array}$ & 0.1196 & $\begin{array}{l}30.64 \\
30.50\end{array}$ & $\begin{array}{l}0.63 \\
0.63\end{array}$ & 0.8772 \\
\hline Crown-rump length $(\mathrm{cm})$ & $\begin{array}{l}\mathrm{T} \\
\mathrm{C}\end{array}$ & $\begin{array}{l}6.68 \\
6.60\end{array}$ & $\begin{array}{l}0.09 \\
0.07\end{array}$ & 0.5009 & $\begin{array}{l}8.73 \\
8.72\end{array}$ & $\begin{array}{l}0.08 \\
0.07\end{array}$ & 0.9498 \\
\hline Nose-rump length $(\mathrm{cm})$ & $\begin{array}{l}\mathrm{T} \\
\mathrm{C}\end{array}$ & $\begin{array}{l}8.24 \\
8.03\end{array}$ & $\begin{array}{l}0.10 \\
0.08\end{array}$ & 0.1164 & $\begin{array}{l}10.46 \\
10.36\end{array}$ & $\begin{array}{l}0.08 \\
0.08\end{array}$ & 0.3488 \\
\hline Total body length $(\mathrm{cm})$ & $\begin{array}{l}\text { 'T } \\
\mathrm{C}\end{array}$ & $\begin{array}{l}15.57 \\
15.16\end{array}$ & $\begin{array}{l}0.32 \\
0.27\end{array}$ & 0.3329 & $\begin{array}{l}18.80 \\
19.00\end{array}$ & $\begin{array}{l}0.24 \\
0.23\end{array}$ & 0.5676 \\
\hline Skin wt (g) & $\begin{array}{l}\mathrm{T} \\
\mathrm{C}\end{array}$ & $\begin{array}{l}3.15 \\
2.85\end{array}$ & $\begin{array}{l}0.17 \\
0.15\end{array}$ & 0.1995 & $\begin{array}{l}5.82 \\
5.92\end{array}$ & $\begin{array}{l}0.16 \\
0.16\end{array}$ & 0.6859 \\
\hline Carcass wt (g) & $\begin{array}{l}\mathrm{T} \\
\mathrm{C}\end{array}$ & $\begin{array}{l}6.99 \\
6.34\end{array}$ & $\begin{array}{l}0.27 \\
0.23\end{array}$ & 0.0782 & $\begin{array}{l}13.77 \\
13.88\end{array}$ & $\begin{array}{l}0.32 \\
0.32\end{array}$ & 0.8050 \\
\hline Abdominal fat (mg) & $\begin{array}{l}\mathrm{T} \\
\mathrm{C}\end{array}$ & $\begin{array}{l}78.29 \\
75.12\end{array}$ & $\begin{array}{l}4.72 \\
3.94\end{array}$ & 0.6088 & $\begin{array}{l}916.41 \\
816.11\end{array}$ & $\begin{array}{l}76.39 \\
76.39\end{array}$ & 0.3597 \\
\hline
\end{tabular}

The table shows the LSMs and SEs of LSMs calculated for both groups of mice investigated. Number of animals investigated per age class: 4

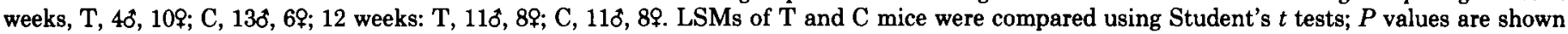
in the fifth and eighth columns, respectively, and significant differences are indicated.

${ }^{a} P<0.001$. 
TABLE 2. Organ weights of PEPCK-IGF-II transgenic mice (T) and nontransgenic littermates (C)

\begin{tabular}{|c|c|c|c|c|c|c|c|}
\hline \multirow{2}{*}{ Organ } & \multirow{2}{*}{ Group } & \multicolumn{3}{|c|}{ Age 4 weeks } & \multicolumn{3}{|c|}{ Age 12 weeks } \\
\hline & & LSM & $\mathbf{S E}$ & $P$ & LSM & SE & $P$ \\
\hline Heart (mg) & $\begin{array}{l}\mathrm{T} \\
\mathrm{C}\end{array}$ & $\begin{array}{l}93.06 \\
85.36\end{array}$ & $\begin{array}{l}3.25 \\
2.71\end{array}$ & 0.0794 & $\begin{array}{l}155.75 \\
159.46\end{array}$ & $\begin{array}{l}4.57 \\
4.57\end{array}$ & 0.5693 \\
\hline Lung (mg) & $\begin{array}{l}\mathrm{T} \\
\mathrm{C}\end{array}$ & $\begin{array}{l}151.38 \\
148.95\end{array}$ & $\begin{array}{l}3.45 \\
2.88\end{array}$ & 0.5926 & $\begin{array}{l}223.68 \\
218.57\end{array}$ & $\begin{array}{l}4.92 \\
4.92\end{array}$ & 0.4678 \\
\hline Spleen (mg) & $\begin{array}{l}\mathrm{T} \\
\mathrm{C}\end{array}$ & $\begin{array}{r}104.35 \\
96.61\end{array}$ & $\begin{array}{l}4.52 \\
3.77\end{array}$ & 0.1990 & $\begin{array}{l}136.88 \\
131.46\end{array}$ & $\begin{array}{l}9.92 \\
9.92\end{array}$ & 0.7021 \\
\hline Pancreas (mg) & $\begin{array}{l}\mathrm{T} \\
\mathrm{C}\end{array}$ & $\begin{array}{l}20.75 \\
26.98\end{array}$ & $\begin{array}{l}3.36 \\
2.56\end{array}$ & 0.1520 & $\begin{array}{l}50.36 \\
55.51\end{array}$ & $\begin{array}{l}6.98 \\
6.98\end{array}$ & 0.6054 \\
\hline Kidney (mg) & $\begin{array}{l}\mathrm{T} \\
\mathrm{C}\end{array}$ & $\begin{array}{r}110.10 \\
94.59\end{array}$ & $\begin{array}{l}4.73 \\
3.95\end{array}$ & $\underset{a}{0.0177}$ & $\begin{array}{l}218.06 \\
206.97\end{array}$ & $\begin{array}{l}8.46 \\
8.29\end{array}$ & 0.3562 \\
\hline Adrenal gland (mg) & $\begin{array}{l}\mathrm{T} \\
\mathrm{C}\end{array}$ & $\begin{array}{l}2.58 \\
2.37\end{array}$ & $\begin{array}{l}0.19 \\
0.16\end{array}$ & 0.4196 & $\begin{array}{l}5.27 \\
4.50\end{array}$ & $\begin{array}{l}0.25 \\
0.25\end{array}$ & $\underset{a}{0.0341}$ \\
\hline Liver (mg) & $\begin{array}{l}\mathrm{T} \\
\mathrm{C}\end{array}$ & $\begin{array}{l}999.65 \\
912.46\end{array}$ & $\begin{array}{l}46.41 \\
38.72\end{array}$ & 0.1599 & $\begin{array}{l}1556.61 \\
1649.47\end{array}$ & $\begin{array}{l}50.05 \\
50.05\end{array}$ & 0.1983 \\
\hline Gastroenteric tract (g) & $\begin{array}{l}\mathrm{T} \\
\mathrm{C}\end{array}$ & $\begin{array}{l}3.18 \\
2.91\end{array}$ & $\begin{array}{l}0.12 \\
0.10\end{array}$ & 0.1020 & $\begin{array}{l}4.34 \\
4.23\end{array}$ & $\begin{array}{l}0.17 \\
0.17\end{array}$ & 0.6248 \\
\hline Thymus (mg) & $\begin{array}{l}\mathrm{T} \\
\mathrm{C}\end{array}$ & $\begin{array}{l}97.87 \\
89.32\end{array}$ & $\begin{array}{l}6.63 \\
5.53\end{array}$ & 0.3308 & $\begin{array}{l}55.23 \\
52.52\end{array}$ & $\begin{array}{l}2.84 \\
2.84\end{array}$ & 0.5043 \\
\hline Salivary gland (mg) & $\begin{array}{l}\mathrm{T} \\
\mathrm{C}\end{array}$ & $\begin{array}{l}133.17 \\
135.83\end{array}$ & $\begin{array}{l}6.73 \\
5.62\end{array}$ & 0.7643 & $\begin{array}{l}227.69 \\
231.83\end{array}$ & $\begin{array}{l}10.53 \\
10.53\end{array}$ & 0.7823 \\
\hline Brain (mg) & $\begin{array}{l}\mathrm{T} \\
\mathrm{C}\end{array}$ & $\begin{array}{l}430.92 \\
423.22\end{array}$ & $\begin{array}{l}4.06 \\
3.39\end{array}$ & 0.1566 & $\begin{array}{l}446.26 \\
446.89\end{array}$ & $\begin{array}{l}6.14 \\
6.14\end{array}$ & 0.9419 \\
\hline Testis (mg) & $\begin{array}{l}\mathrm{T} \\
\mathrm{C}\end{array}$ & $\begin{array}{l}52.11 \\
40.37\end{array}$ & $\begin{array}{l}2.79 \\
1.55\end{array}$ & $\underset{b}{0.0022}$ & $\begin{array}{r}93.82 \\
102.64\end{array}$ & $\begin{array}{l}4.65 \\
4.65\end{array}$ & 0.1950 \\
\hline
\end{tabular}

The table shows the LSMs and SEs of LSMs calculated for both groups of mice investigated. Number of animals investigated per age class: 4

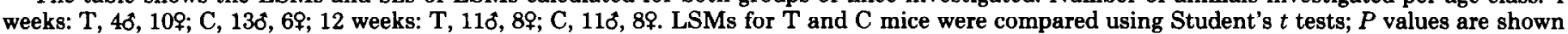
in the fifth and eighth columns, respectively, and significant differences are indicated.

${ }^{a} P<0.05$.

${ }^{b} P<0.01$.

transgene, which was also seen in our study.

As a consequence of PEPCK-IGF-II transgene expression, we observed a number of endocrine changes. A negative relationship between serum IGF-II and IGF-I levels in PEPCK-IGF-II transgenic mice might be due to displacement by IGF-II of IGF-I from IGFBPs, mainly IGFBP-3, which is the most abundant IGFBP in the circulation $(40,41)$. IGFBP3 was slightly, but not significantly, elevated in PEPCK-IGFII transgenic mice. The IGF levels measured reflect almost exclusively IGF peptides bound to IGFBPs, as the half-lives of free IGFs in the circulation are very short (42). In contrast to PEPCK-IGF-II transgenic mice, circulating IGFBP-3 increased significantly in IGF-I transgenic mice in both the presence and absence of $\mathrm{GH}$, suggesting that IGF-I, rather than $\mathrm{GH}$, is the primary regulator of serum IGFBP-3 (43). Furthermore, a recent study showed elevated IGF-I and IGFBP-3 serum levels in transgenic mice with inducible ovine $\mathrm{GH}$ gene expression (44). However, this model is not suitable to separate the effects of IGF-I on circulating IGFBP-3 levels from those of $\mathrm{GH}$.

Overexpression of IGF-I in transgenic mice was also found to stimulate increases in serum IGFBP-2 (43). IGFBP-2 is the second most abundant IGFBP in the circulation and may act primarily as an IGF-II-BP, as its affinity for IGF-Il is 1 order of magnitude higher than that for IGF-I (45). A comparison of mouse, rat, and human IGFBP-2 sequences revealed a high degree of homology among all three species (46). Although little is known so far about the regulation of IGFBP2 , a working hypothesis has emerged that IGFBP-2 is mainly regulated by its primary ligand, IGF-II (23). PEPCK-IGF-II transgenic mice show significantly elevated serum IGFBP-2, with a sex-related difference mirroring that observed with IGF-II. Furthermore, linear regression analysis revealed a significant positive correlation between IGF-II and IGFBP-2 levels in PEPCK-IGF-II transgenic mice, providing direct experimental evidence that IGF-II is a major regulator of IGFBP-2. The significant negative correlation between IGF-I and IGFBP-2 may primarily be due to the negative relationship between IGF-I and IGF-II. Although IGF-I is capable of increasing serum IGFBP-2 (43), up-regulation of IGFBP-2 obviously does not depend on an increase in serum IGF-I.

The observation that in both groups of mice animals 
younger than 12 weeks had significantly higher IGFBP-2 values than older animals is consistent with findings in humans, in which IGFBP-2 levels are high at birth, decline by late puberty, and increase again with aging (23). IGFBP2 was up-regulated by fasting, which was also found in humans (23) and rats (47). The greater increase in IGFBP-2 levels in transgenic mice $(70 \%)$ than in controls $(40 \%)$ indicates a synergistic effect of elevated IGF-II and fasting on IGFBP-2 levels.

Fasting insulin concentrations in serum from PEPCK-IGFII transgenic mice were significantly lower than those in controls. A reduction of insulin levels is also found in patients suffering from nonislet cell tumor-induced hypoglycemia due to large tumors producing excessive amounts of IGF-II or its prohormone forms (48). In contrast to these patients, PEPCK-IGF-II transgenic mice are not hypoglycemic. This may be due to a difference in the absolute level of IGF-II produced or a difference in the relative amount of IGFBPs that could block the hypoglycemic action of excessive IGFII. IGFBP-3 is low in nonislet cell tumor-induced hypoglycemia, and its increase after $\mathrm{GH}$ therapy results in alleviation of hypoglycemia (49). A study of the acute action of IGF-II on glucose metabolism in adult rats showed that compared to insulin, about 50 times higher doses of IGF-II were required to produce identical in vivo responses (50). The hypothesis that the development of hypoglycemia as a consequence of elevated IGF-II may be dose dependent is supported by a recently published study on transgenic mice expressing IGF-II under the transcriptional control of the MUP promoter (51). A line of mice with a mean circulating IGF-II level of $454 \mathrm{ng} / \mathrm{ml}$ showed a $20 \%$ reduction in glucose levels throughout life; another transgenic line with an average serum IGF-II level of $243 \mathrm{ng} / \mathrm{ml}$ developed hypoglycemia with increasing age. Furthermore, a large reduction in body fat was observed in both of these lines, but the mechanism for this metabolic effect of IGF-II is still unclear. Our estimations of the body compositions of 4- and 12-week-old PEPCK-IGF-II transgenic mice did not suggest a significant reduction in body fat.

In addition to a number of endocrine consequences, elevated IGF-II in transgenic mice had subtle effects on the growth of several organs, which can at least in part be explained by findings of other studies. The roles of different growth factors, including IGFs, in kidney development have recently been reviewed by Hammerman et al. (52). IGF-II is expressed in human fetal kidney, mainly in undifferentiated stromal and blastemal cells (53). Furthermore, IGF-I and IGF-II are required for the growth and development of rat metanephroi in vitro (54). In vivo, compensatory renal growth after unilateral nephrectomy in immature, but not adult, rats was associated with increased renal IGF-I gene expression and enhanced specific renal binding of IGF-I and IGF-II to plasma membranes (55). In another study, elevated IGF-II levels were found in kidney tissue and serum of immature, but not adult, rats during compensatory kidney growth after uninephrectomy (56). Conversely, kidney weight was increased in nude mice transplanted with pieces of IGF-IIsecreting Wilms' tumors (36). As nephrogenesis of mice is not completed with birth (57) and PEPCK promoter-driven IGF-II expression in the kidney starts around birth, there is a common window for both phenomena that could explain the slightly, but significantly, increased kidney weight of PEPCK-IGF-II transgenic mice at the age of 4 weeks. Complex stereological investigations will be necessary to determine the organ structures undergoing increased growth and to clarify why the difference in kidney weight is decreased at the age of 12 weeks.

The effects of IGF-II on the adrenal gland are also well known. Quantitation and localization of IGF-II mRNA in the developing ovine adrenal gland provided evidence for an autocrine/paracrine role of IGF-II in vivo (58). In vitro studies on fetal rat (59) or human adrenal cells (60) demonstrated a proliferative effect of IGF-II. Furthermore, IGF-II, more potently than IGF-I, stimulated bovine adrenocortical steroidogenesis through the IGF type 1 receptor (61).

Although we observed distinct effects of IGF-II overexpression on organ growth in transgenic mice, they were relatively small compared to those in transgenic mice expressing human IGF-I (62-64) or GHs from different species (for review, see Ref. 65). These studies demonstrated that the growth-promoting actions of $\mathrm{GH}$ are in large part mediated by IGF-I, but also suggested that GH and IGF-I act independently in specific tissues; GH appears to stimulate liver growth directly, whereas IGF-I has a specific GH-independent effect on brain growth (for review, see Ref. 66).

The lack of major changes in body and organ growth of PEPCK-IGF-II transgenic mice may be due to relatively high levels of IGF-I persisting in these animals. The growth effects of IGF-II are probably mediated via the IGF type 1 receptor, which usually binds IGF-I with higher affinity than IGF-II (for review, see Ref. 67).

A synthesis of our results and findings of studies on mice expressing IGF-II transgenes with different tissue specificities [part only available in abstract form (68-70)] will further specify the endocrine and auto-/paracrine effects of IGF-II. Specifically, it will be interesting to determine whether aging PEPCK-IGF-II transgenic mice develop tumors with increased frequency, as has been observed in MUP-IGF-II transgenic mice (51).

\section{Acknowledgments}

We would like to thank Prof. $H$. Thoenen for his generous support of the project; Drs. W. Kiess, R. Wanke, and N. Smyth for critically reading the manuscript; $K$. Schmitt, $H$. Heimann, J. Grassl, and U. Huffstadt for excellent technical assistance; and $\mathrm{H}$. Beck and A. Ciolovan for expert care of the animals.

\section{References}

1. Sara VR, Hall K 1990 Insulin-like growth factors and their binding proteins. Physiol Rev 70:591-614

2. Humbel RE 1990 Insulin-like growth factors I and II. Eur J Biochem 190:445-462

3. DeChiara TM, Efstratiadis A, Robertson EJ 1990 A growth-deficiency phenotype in heterozygous mice carrying an insulin-like growth factor Il gene disrupted by targeting. Nature 345:78-80

4. DeChiara TM, Robertson EJ, Efstratiadis A 1991 Parental imprinting of the mouse insulin-like growth factor II gene. Cell 64:849-859 
5. Harvey MB, Kaye PL 1992 IGF-2 stimulates growth and metabolism of early mouse embryos. Mech Dev 38:169-174

6. Soares MB, Ishii DN, Efstratiadis A 1985 Developmental and tissue-specific expression of a family of transcripts related to rat insulin-like growth factor II mRNA. Nucleic Acids Res 13:11191134

7. Murphy LJ, Bell GI, Friesen HG 1987 Tissue distribution of insulinlike growth factor I and II messenger ribonucleic acid in the adult rat. Endocrinology 120:1279-1282

8. Rotwein P, Burgess SK, Milbrandt JD, Krause JE 1988 Differential expression of insulin-like growth factor genes in rat central nervous system. Proc Natl Acad Sci USA 85:265-269

9. Zapf J, Walter H, Froesch ER 1981 Radioimmunological determination of insulinlike growth factors I and II in normal subjects and in patients with growth disorders and extrapancreatic tumor hypoglycemia. J Clin Invest 68:1321-1330

10. Blum WF, Ranke MB, Bierich JR 1988 A specific radioimmunoassay for insulin-like growth factor II: the interference of IGF binding proteins can be blocked by excess IGF-I. Acta Endocrinol (Copenh) 118:374-380

11. de Pagter-Holthuizen $P$, Jansen $M$, van Schaik FMA, van der Kammen R, Oosterwijk C, Van den Brande JL, Sussenbach JS 1987 The human insulin-like growth factor II gene contains two development-specific promoters. FEBS Lett 214:259-264

12. Schofield PN, Tate VE 1987 Regulation of human IGF-II transcription in fetal and adult tissues. Development 101:793-803

13. Schofield PN, Engstrom W 1992 Insulin-like growth factors in human cancer. In: Schofield PN (ed) The Insulin-Like Growth Factors: Structure and Biological Functions. Oxford University Press, Oxford, New York, and Tokyo, pp 240-257

14. Cariani E, Dubois N, Lasserre C, Briand P, Brechot C 1991 Insulinlike growth factor II (IGF-II) mRNA expression during hepatocarcinogenesis in transgenic mice. J Hepatol 13:220-226

15. Schirmacher P, Held WA, Yang D, Chisari FV, Rustum Y, Rogler CE 1993 Reactivation of insulin-like growth factor II during hepatocarcinogenesis in transgenic mice suggests a role in malignant growth. Cancer Res 52:2549-2556

16. Dull TJ, Gray A, Hayflick JS, Ullrich A 1984 Insulin-like growth factor Il precursor gene organization in relation to insulin gene family. Nature 310:777-781

17. Le Bouc $Y$, Noguiez $P$, Sondermeijer $P$, Dreyer D, Girard $F$, Binoux M 1987 A new 5' -non-coding region for human placental insulin-like growth factor II mRNA expression. FEBS Lett 222:181185

18. Ausubel FM, Brent R, Kingston RE, Moore DD, Seidman JG, Smith JA, Struhl K 1987 Current Protocols in Molecular Biology. Wiley and Sons, New York

19. Wolf E, Rapp K, Brem G 1991 Expression of metallothioneinhuman growth hormone fusion genes in transgenic mice results in disproportionate skeletal gigantism. Growth Dev Aging 55:117-127

20. Okayama $H$, Kawaichi $M$, Brownstein M, Lee $F$, Yokota T, Arai K 1987 High-efficiency cloning of full-length cDNA; construction and screening of cDNA libraries for mammalian cells. Methods Enzymol 154:3-28

21. Sambrook J, Fritsch EF, Maniatis T 1989 Molecular Cloning $\Lambda$ Laboratory Manual. Cold Spring Harbor Laboratory, Cold Spring Harbor

22. Blum WF, Gallaher B, Ranke MB, An IGFBP-blocked IGF-I RIA that measures what it pretends to measure: IGF-I. 74th Annual Meeting of The Endocrine Society, San Antonio TX, 1992, p 293 (Abstract)

23. Blum WF, Horn N, Kratzsch J, Jørgensen JOL, Juul A, Teale D, Mohnike K, Ranke MB 1993 Clinical studies of IGFBP-2 by radioimmunoassay. Growth Regul 3:100-103

24. Hossenlopp P, Seurin D, Segovia-Quinson B, Hardouin S, Binoux M 1986 Analysis of serum insulin-like growth factor binding proteins using Western blotting: use of the method for titration of the binding proteins and competitive binding studies. Anal Biochem 154:138-143

25. Zapf J, Schmid C, Guler HP, Waldvogel M, Hauri C, Futo E, Hossenlopp P, Binoux M, Froesch ER 1990 Regulation of binding proteins for insulin-like growth factors (IGF) in humans: increased expression of IGF binding protein 2 during IGF I treatment of healthy adults and in patients with extrapancreatic tumor hypoglycemia. J Clin Invest 86:952-961

26. Wolf E, Wanke R, Hermanns W, Brem G, Pirchner F, von ButlerWemken I 1991 Growth characteristics of metallothionein-human growth hormone transgenic mice as compared to mice selected for high eight-week body weight and unselected controls. I. Body weight gain and external body dimensions. Growth Dev Aging 55:225-235

27. Hull P 1960 Genetic relations between carcass fat and body weight in mice. J Agric Sci 53:317-321

28. SAS Institute Inc. 1988 SAS/STAT User's Guide, version 6.03. SAS Institute, Cary, pp 549-640

29. Palmiter RD, Sandgren EP, Avarbock MR, Allen DD, Brinster RL 1991 Heterologous introns can enhance expression of transgenes in mice. Proc Natl Acad Sci USA 88:478-482

30. McGrane MM, de Vente J, Yun J, Bloom J, Park E, WynshawBoris A, Wagner T, Rottman FM, Hanson RW 1988 Tissue-specific expression and dietary regulation of a chimeric phosphoenolpyruvate carboxykinase/bovine growth hormone gene in transgenic mice. I Biol Chem 263:11443-11451

31. McGrane MM, Yun JS, Moorman AFM, Lamers WH, Hendrick GK, Arafah BM, Park EA, Wagner TE, Hanson RW 1990 Metabolic effects of developmental, tissue-, and cell-specific expression of a chimeric phosphoenolpyruvate carboxykinase (GTP)/bovine growth hormone gene in transgenic mice. J Biol Chem 265:22371-22379

32. Baker J, Liu J-P, Robertson EJ, Efstratiadis A 1993 Role of insulinlike growth factors in embryonic and postnatal growth. Cell 75:7382

33. Liu J-P, Baker J, Perkins AS, Robertson EJ, Efstratiadis A 1993 Mice carrying null mutations of the genes encoding insulin-like growth factor I (Igf-1) and type 1 IGF receptor (Igf1r). Cell 75:5972

34. Powell-Braxton L, Hollingshead P, Warburton C, Dowd M, PittsMeek S, Dalton D, Gillett N, Stewart TA 1993 IGF-I is required for normal embryonic growth in mice. Genes Dev 7:2609-2617

35. Wilson DM, Thomas JA, Hamm TE, Wyche J, Hintz RL, Rosenfeld RG 1987 Transplantation of IGF-II secreting tumours into nude rodents. Endocrinology 120:1896-1901

36. Ren-Qiu Q, Ruelicke T, Hassam S, Haselbacher GK, Schoenle EJ 1993 Systemic effects of insulin-like growth factor-II produced and released from Wilms' tumour tissue. Eur ] Pediatr 152:102-106

37. Eisenberger $\mathbf{C L}$, Nechushtan $H$, Cohen $H$, Shani $M$, Reshef $L$ 1992 Differential regulation of the rat phosphoenolpyruvate carboxykinase gene expression in several tissues of transgenic mice. Mol Cell Biol 12:1396-1403

38. Short MK, Clouthier DE, Schaefer IM, Hammer RE, Magnuson MA, Beale EG 1992 Tissue-specific, developmental, hormonal, and dietary regulation of rat phosphoenolpyruvate carboxykinase-human growth hormone fusion genes in transgenic mice. Mol Cell Biol 12:1007-1020

39. McGrane MM, Yun JS, Roesler WJ, Park EA, Wagner TE, Hanson RW 1990 Developmental regulation and tissue-specific expression of a chimaeric phosphoenolpyruvate carboxykinase/bovine growth hormone gene in transgenic animals. J Reprod Fertil [Suppl] 41:1723

40. Baxter RC, Martin JL 1986 Radioimmunoassay of growth hormonedependent insulin-like growth factor binding protein in human plasma. J Clin Invest 78:1504-1512

41. Blum WF, Ranke MB, Kietzmann K, Gauggel E, Zeisel H], Bierich JR 1990 A specific radioimmunoassay for the growth hormone (GH)-dependent somatomedin-binding protein: its use for diagnosis of GH deficiency. J Clin Endocrinol Metab 70:1292-1298

42. Guler HP, Zapf J, Schmid C, Froesch ER 1989 Insulin-like growth factors I and II in healthy man. Estimations of half-lives and production rates. Acta Endocrinol (Copenh) 121:753-758

43. Camacho-Hubner C, Clemmons DR, D'Ercole AJ 1991 Regulation of insulin-like growth factor (IGF) binding proteins in transgenic mice with altered expression of growth hormone and IGF-I. Endocrinology 129:1201-1206

44. Chow JC, Murray JD, Pomp D, Baldwin RL, Calvert CC, Oberbauer AM 1994 Regulation of insulin-like growth factor-I and 
binding protein-3 expression in oMtla-oGH transgenic mice. Transgen Res 3:127-133

45. Binkert C, Landwehr J, Mary J-L, Schwander J, Heinrich G 1989 Cloning, sequence analysis and expression of a cDNA encoding a novel insulin-like growth factor binding protein (IGFBP-2). EMBO J 8:2497-2502

46. Landwehr J, Kaupmann K, Heinrich G, Schwander J 1993 Cloning and characterization of the gene encoding murine insulin-like growth factor-binding protein-2, mIGFBP-2. Gene 124:281-286

47. Tseng LY-H, Ooi GT, Brown AL, Straus DS, Rechler MM 1992 Transcription of the insulin-like growth factor-binding protein-2 gene is increased in neonatal and fasted adult rat liver. Mol Endocrinol 6:1195-1201

48. Daughaday WH, Trivedi B, Kapadia M 1981 Measurement of insulin-like growth factor II by a specific radioreceptor assay in serum of normal individuals, patients with abnormal growth hormone secretion and patients with tumour associated hypoglycemia. J Clin Endocrinol Metab 53:282-288

49. Teale JD, Blum WF, Marks V 1992 Alleviation of non-islet cell tumour hypoglycaemia by growth hormone therapy is associated with changes in IGF binding protein-3. Ann Clin Biochem 29:314323

50. Stümpel F, Hartmann H 1992 Acute actions of insulin-like growth factor II on glucose metabolism in adult rats. Diabetologia 35:932 938

51. Rogler CE, Yang D, Rossetti L, Donohoe J, Alt E, Chang CJ, Rosenfeld R, Neely K, Hintz R 1994 Altered body composition and increased frequency of diverse malignancies in insulin-like growth factor-II transgenic mice. J Biol Chem 269:13779-13784

52. Hammerman MR, Rogers SA, Ryan G 1993 Growth factors and kidney development. Pediatr Nephrol 7:616-620

53. Hirvonen $H$, Sandberg $M$, Kalimo $H$, Hukkanen $V$, Vuorio $E$, Salmi TT, Alitalo K 1989 The N-myc proto-oncogene and IGF II growth factor mRNAs are expressed by distinct cells in human fetal kidney and brain. J Cell Biol 108:1093-1104

54. Rogers SA, Ryan G, Hammerman MR 1991 Insulin-like growth factors I and II are produced in the metanephros and are required for growth and development in vitro. J Cell Biol 113:1447-1453

55. Mulroney EE, Haramati A, Werner $H$, Bondy $C$, Roberts Jr CT LeRoith D 1992 Altered expression of insulin-like growth factor-I (IGF-I) and IGF receptor genes after unilateral nephrectomy in immature rats. Endocrinology 130:249-256

56. Rosendahl W, Föll J, Blum W, Ranke MB 1992 Increased insulinlike growth factor-II tissue concentrations during compensatory kidney growth in infantile rats. Pediatr Nephrol 6:527-531

57. Hanai T, Usuda N, Morita T, Shimizu T, Nagata T 1993 Proliferative activity in the kidneys of aging mice evaluated by PCNA/ cyclin immunohistochemistry. Cell Mol Biol 39:181-191
58. Han VKM, Lu F, Bassett N, Yang KP, Delhanty PJ, Challis JRG 1992 Insulin-like growth factor-II (IGF-II) messenger ribonucleic acid is expressed in steroidogenic cells of the developing ovine adrenal gland: evidence of an autocrine/paracrine role for IGF-II. Endocrinology 131:3100-3109

59. van Dijk JP, Tanswell AK, Challis JR 1988 Insulin-like growth factor (IGF)-II and insulin, but not IGF-I, are mitogenic for fetal rat adrenal cells in vitro. J Endocrinol 119:509-516

60. Mesiano S, Mellon SH, Jaffe RB 1993 Mitogenic action, regulation, and localization of insulin-like growth factors in the human fetal adrenal gland. J Clin Endocrinol Metab 76:968-976

61. Weber MM, Simmler P, Engelhardt D 1994 IGF-II more potently than IGF-I stimulates bovine adrenal steroidogenesis through interaction with the IGF-I receptor and IGF binding proteins. Exp Clin Endocrinol [Suppl 1] 102:187 (Abstract)

62. Mathews LS, Hammer RE, Behringer RR, D'Ercole AJ, Bell GI, Brinster RL, Palmiter RD 1988 Growth enhancement of transgenic mice expressing human insulin-like growth factor I. Endocrinology 123:2827-2833

63. Behringer RR, Lewin TM, Quaife CJ, Palmiter RD, Brinster RL, D'Ercole AJ 1990 Expression of insulin-like growth factor I stimulates normal somatic growth in growth hormone-deficient transgenic mice. Endocrinology 127:1033-1040

64. Carson MJ, Behringer RR, Brinster RL, McMorris FA 1993 Insulin-like growth factor I increases brain growth and central nervous system myelination in transgenic mice. Neuron 10:729-740

65. Wanke $R$, Wolf E, Hermanns W, Folger $S$, Buchmüller $T$, Brem G 1992 The GH-transgenic mouse as an experimental model for growth research: clinical and pathological studies. Horm Res [Suppl 3] 37:74-87

66. D'Ercole AJ 1993 Expression of insulin-like growth factor-I in transgenic mice. Ann NY Acad Sci 692:149-160

67. Moxham C, Jacobs S 1992 Insulin-like growth factor receptors. In: Schofield PN (ed) The Insulin-Like Growth Factors: Structure and Biological Functions. Oxford University Press, Oxford, New York, and Tokyo, pp 80-109

68. van Buul-Offers SC, de Haan K, Reijnen-Gresnigt MG, Meinsma $D$, Jansen $M$, Van den Brande JL, Overexpression of human IGFII in transgenic mice causes increased growth of the thymus. 75th Annual Meeting of The Endocrine Society, Las Vegas NV, 1993, p 214 (Abstract)

69. Kooijman R, van Buul-Offers SC, Scholtens EJ, Rijkers GT, Zegers BJM $1994 \mathrm{~T}$ cell development in IGF-II transgenic mice. Growth Regul [Suppl 1] 4:124 (Abstract)

70. Ward A, Bates P, Fisher R, Richardson L, Graham CF 1994 Transgenic mice bearing extra copies of the insulin-like growth factor II gene exhibit selective organomegaly. Growth Regul [Suppl 1) 4:126 (Abstract) 